\title{
PENERAPAN TRIPLE EXPONENTIAL SMOOTHING DALAM MERAMALKAN LAJU INFLASI BULANAN PROVINSI ACEH TAHUN 2019 - 2020
}

\author{
Viza Fitria ${ }^{1}$ \\ Samsul Anwar ${ }^{2}$ \\ Fakultas Matematika dan Ilmu Pengetahuan Alam Universitas Syiah Kuala, Aceh, \\ Indonesia ${ }^{1,2}$ \\ Email: samsul.anwar@unsyiah.ac.id
}

\begin{abstract}
The inflation rate shows the percentage of price increasing of goods and services in general at a particular region and time. The general increase in the inflation rate is caused by an increase in the money supply that exceeds economic growth, the rupiah exchange rate, and also a high demand for goods. Triple Exponential Smoothing method is one of the forecasting methods in time series data that is used when data shows the existence of seasonal trends and behavior. The purpose of this study is to forecast the monthly inflation rate of Aceh Province in 2019-2020. The data used is the monthly inflation data of Aceh Province starting from January 2011 to December 2018. The best Triple Exponential Smoothing model for forecasting the inflation rate is a model with alpha $(\alpha)$ $=0.045$, beta $(\beta)=0.034$, and gamma $(\gamma)=0.49$. The results show that forecasting data tends to follow the previous data pattern. The monthly inflation rate in Aceh Province tends to rise in June and December and is low in February to April. The monthly inflation rate of Aceh Province in 2019 is expected to be in the range of -0.41 to 0.71. While in 2020, the inflation rate of Aceh Province is estimated to be in the range of -0.47 to 0.65 .
\end{abstract}

Key words: inflation; forecasting; Aceh Province; triple exponential smoothing.

\begin{abstract}
ABSTRAK
Laju inflasi menunjukkan persentase kenaikan harga barang dan jasa secara umum dalam suatu wilayah dan waktu tertentu. Peningkatan laju inflasi secara umum disebabkan oleh peningkatan jumlah uang beredar yang melebihi pertumbuhan ekonomi, nilai tukar rupiah, dan juga adanya permintaan tinggi terhadap suatu barang. Metode Triple Exponential Smoothing adalah salah satu metode peramalan dalam data deret waktu yang digunakan ketika data menunjukan adanya trend dan perilaku musiman. Tujuan dari penelitian ini adalah untuk meramalkan laju inflasi bulanan Provinsi Aceh tahun 2019 - 2020. Data yang digunakan adalah data laju inflasi bulanan Provinsi Aceh mulai dari bulan Januari 2011 sampai dengan bulan Desember 2018. Model Triple Exponential Smoothing terbaik untuk meramalkan laju inflasi tersebut adalah model dengan parameter alpha $(\alpha)$ $=0,045$; beta $(\beta)=0,034$ dan gamma $(\gamma)=0,49$. Hasil penelitian menunjukkan bahwa data peramalan cenderung untuk mengikuti pola data sebelumnya. Laju inflasi bulanan di Provinsi Aceh cenderung naik pada bulan Juni dan Desember dan rendah pada bulan Februari hingga April. Laju inflasi bulanan Provinsi Aceh tahun 2019 diperkirakan akan berada pada kisaran -0,41 sampai 0,71. Sedangkan pada tahun 2020, laju inflasi Provinsi Aceh diperkirakan akan berada pada kisaran -0,47 sampai 0,65 .
\end{abstract}

Kata kunci: inflasi; peramalan; Provinsi Aceh; triple exponential smoothing. 


\section{PENDAHULUAN}

Inflasi adalah kenaikan jangka panjang dalam harga barang dan jasa yang disebabkan oleh devaluasi mata uang. Inflasi diukur dalam berbagai cara tergantung pada jenis barang dan jasa yang dipertimbangkan, dan merupakan kebalikan dari deflasi yang menunjukkan penurunan umum dalam harga barang dan jasa ketika tingkat inflasi berada di bawah nol persen. Kestabilan laju inflasi merupakan hal yang sangat penting karena berkaitan dengan pertumbuhan ekonomi yang akan berdampak pada peningkatan kesejahteraan masyarakat. Pada saat terjadinya inflasi yang tinggi, harga barang dan jasa akan naik terus menerus dan menyebabkan masyarakat tidak mampu memenuhi kebutuhan hidup. Apabila pendapatan tidak meningkat seiring dengan kenaikan harga barang, maka daya beli masyarakat akan berkurang secara signifikan dan pada akhirnya dapat menyebabkan pertumbuhan ekonomi yang melambat atau stagnan.

Pergerakkan laju inflasi Provinsi Aceh berfluktuasi setiap tahunnya. Berdasarkan publikasi BPS Provinsi Aceh (2018a) dalam buku Perkembangan Indikator Sosial Ekonomi Provinsi Aceh tahun 2018, laju inflasi Provinsi Aceh pada tahun 2014 mencapai 8,09\% dan menurun drastis pada tahun 2015 menjadi 1,53\%. Inflasi Provinsi Aceh kembali meningkat pada tahun 2016 dan 2017 masing-masing mencapai 3,95\% dan 4,18\%, dan kembali menurun pada tahun 2018 menjadi sebesar $1,84 \%$.

Pentingnya pengendalian laju inflasi didasarkan pada pertimbangan bahwa laju inflasi yang tinggi dan tidak stabil akanmemberikan dampak negatif terhadap kondisi perekonomian daerah. Laju inflasi bulanan Provinsi Aceh untuk beberapa 
tahun ke depan perlu diramalkan sebagai upaya dalam menjaga stabilitasnya. Peramalan inflasi tersebut berguna untuk memperkirakan laju inflasi yang mungkin akan terjadi di Provinsi Aceh, sehingga dapat dipersiapkan berbagai kebijakan untuk mencegah kemungkinan terjadinya inflasi yang tinggi tersebut pada masa yang akan datang.

Dalam penelitian ini, metode peramalan triple exponential smoothing akan digunakan untuk meramalkan laju inflasi bulanan Provinsi Aceh untuk periode 2019-2020. Metode ini terbukti mampu memberikan hasil peramalan yang akurat seperti yang dilakukan dalam beberapa penelitian misalnya oleh Nasution, Anwar, Fitri, \& Zohra (2019) mengenai peramalan jumlah ikan tuna/ madidihang (Yellowfin tuna) yang didaratkan di PPS Kutaraja Kota Banda Aceh, Pranata, Akbar Hsb, Akhdansyah, \& Anwar (2018) tentang peramalan jumlah kunjungan wisatawan mancanegara ke Indonesia dan Fitri, Anwar, Zohra, \& Nasution (2018) tentang peramalan laju inflasi bulanan Kota Padang. Metode triple exponential smoothing memiliki kelebihan jika dibandingkan dengan metode Autoregressive Integrated Moving Average (ARIMA). Peramalan dengan metode triple exponential smoothing akan menghasilkan ramalan yang cukup stabil meskipun jumlah periode ramalan ditambah. Menurut Anwar (2017), keakuratan hasil peramalan dengan metode ARIMA akan semakin meningkat apabila jumlah periode yang akan diramalkan semakin diperkecil. Sehingga metode triple exponential smoothing lebih cocok untuk diterapkan dalam meramalkan laju inflasi bulanan Provinsi Aceh tahun 2019-2020 


\section{METODE PENELITIAN}

Data yang digunakan dalam penelitian ini adalah data laju inflasi bulanan Provinsi Aceh mulai dari bulan Januari 2011 sampai dengan bulan Desember 2018 yang bersumber dari Badan Pusat Statistik Provinsi Aceh (BPS Provinsi Aceh, 2011, 2012, 2013, 2014, 2015, 2016, 2017, 2018b). Penelitian ini dilakukan dengan menggunakan analisis deskriptif dan analisis inferensia. Pada analisis deskriptif dilakukan plotting untuk menggambarkan pola data yang digunakan serta melihat karakteristik sebaran data. Pada analisis inferensia dilakukan pemodelan dan peramalan dengan menggunakan metode triple exponential smoothing. Pada analisis inferensia, data dibagi menjadi 2, yaitu data training (mulai dari bulan Januari 2011 sampai dengan bulan Desember 2017) dan data testing (mulai dari bulan Januari 2018 sampai dengan bulan Desember 2018). Proses pengolahan data dalam penelitian ini dengan menggunakan bantuan software R dan Microsoft Excel.

Adapun tahapan dalam peramalan laju inflasi bulanan Provinsi Aceh dengan menggunakan metode triple exponential smoothing adalah sebagai berikut : 1). Membuat plot data untuk mengetahui pola dari data yang digunakan. 2). Membagi data menjadi data training dan data testing. 3). Membangun beberapa model tentatif dengan parameter pemulusan $(\alpha, \beta, \gamma)$ yang bervariasi dari data training. 4). Meramalkan data testing berdasarkan model tentatif yang dibangun dari data training. 5). Memilih model terbaik untuk data testing dari beberapa model tentatif dengan membandingkan nilai error terkecil. Indikator yang digunakan untuk menghitung ketepatan peramalan adalah MSE (Mean Squared 
Error), MAPE (Mean Absolute Percentage Error), dan RMSE (Root Mean Square Error). 6). Meramalan laju inflasi bulanan Provinsi Aceh periode 2019-2020 berdasarkan model terbaik pada tahap 5 .

Berikut merupakan penjelasan singkat mengenai inflasi dan metode triple exponential smoothing yang digunakan dalam penelitian ini. Inflasi adalah suatu keadaan dimana harga barang dan jasa secara umum meningkat atau turunnya daya jual mata uang suatu negara. Secara sederhana, inflasi dapat diartikan sebagai proses kenaikan harga-harga umum secara terus menerus dalam suatu wilayah tertentu (Ferayanti, Masbar, \& Syahnur, 2014). Laju inflasi adalah persentase kenaikan atau penurunan harga selama periode tertentu. Persentase tersebut memberikan gambaran seberapa cepat harga naik atau turun selama periode tertentu.

Peningkatan laju inflasi secara umum disebabkan oleh peningkatan jumlah uang beredar yang melebihi pertumbuhan ekonomi (Yusri, 2016). Peningkatan jumlah uang yang beredar akan mengakibatkan nilai mata uang tersebut turun dan harga barang meningkat. Hasil penelitian yang telah dilakukan oleh Ferayanti et al. (2014) menyimpulkan bahwa nilai tukar rupiah (kurs) juga sangat berpengaruh terhadap laju inflasi. Melemahnya nilai tukar rupiah terhadap mata uang asing menyebabkan harga-harga barang secara umum mengalami kenaikan. Terjadinya inflasi juga disebabkan oleh adanya permintaan atau daya tarik masyarakat yang kuat terhadap suatu barang. Inflasi tersebut terjadi karena munculnya keinginan berlebihan dari masyarakat terhadap barang dan jasa yang tersedia di pasaran. Keinginan yang berlebihan tersebut menyebabkan permintaan menjadi bertambah, 
sedangkan penawaran masih berada pada posisi yang tetap dan pada akhirnya akan mengakibatkan harga barang dan jasa tersebut menjadi naik.

Exponential smoothing (penghalusan exponensial) adalah salah satu teknik peramalan rata-rata bergerak yang melakukan penimbangan terhadap data masa lalu dengan cara eksponensial sehingga data paling akhir mempunyai bobot atau timbangan yang lebih besar dalam rata-rata bergerak (Santoso, 2009). Model ramalan exponential smoothing merupakan salah satu model ramalan untuk data berkala (time series). Metode ini dibagi menjadi tiga, yaitu single exponential smoothing, double exponential smoothing dan triple exponential smoothing.

Metode triple exponential smoothing digunakan ketika data menunjukan adanya trend dan perilaku musiman (Makridakis, Wheelwright, \& Hyndman, 1998). Metode ini merupakan perkembangan dari metode pemulusan eksponensial sederhana yang menggunakan tiga konstanta pemulusan, yaitu unsur stasioner, pemulusan kecenderungan (trend), dan pemulusan musiman (seasonal) dengan menggunakan tiga pembobotan dalam prediksinya, yaitu $\alpha, \beta$ dan $\gamma$. Menurut Holt (2004), $\alpha$ merupakan parameter yang mengontrol penghalusan relatif pada pengamatan yang baru dilakukan, $\beta$ merupakan parameter yang mengontrol penghalusan relatif pada pengamatan yang baru dilakukan untuk mengestimasi kemunculan unsur kecenderungan, dan $\gamma$ merupakan parameter yang mengontrol penghalusan relatif pada pengamatan yang baru dilakukan untuk mengestimasi kemunculan unsur musiman. Parameter $\alpha, \beta$ dan $\gamma$ bernilai konstanta yang nilainya berada diantara 0 dan 1 dan ditentukan secara subjektif atau dengan meminimalkan nilai kesalahan dari estimasi tersebut (Makridakis et al., 1998). 
Persamaan umum metode triple exponential smoothing adalah sebagai berikut (Makridakis et al., 1998):

Pemulusan keseluruhan $\quad: s_{t}=\alpha \frac{x_{t}}{c_{t-L}}(1-\alpha)+\left(s_{t-1}+b_{t-1}\right)$

dengan $s_{0}=x_{0}$

Pemulusan trend

$$
: b_{t}=\beta\left(s_{t}-s_{t-1}\right)+(1-\beta) b_{t-1}
$$

Pemulusan musiman

$$
: c_{t}=\gamma \frac{x_{t}}{s_{t}}+(1-\gamma) c_{t-L}
$$

Nilai peramalan ke- $m$

$$
: F_{t+m}=\left(s_{t}+m b_{t}\right) c_{t-L+m}
$$

Dimana,

$$
\begin{aligned}
& s_{t}=\text { pemulusan keseluruhan periode ke- } t \\
& b_{t}=\text { pemulusan trend period ke- } t \\
& c_{t}=\text { pemulusan musiman periode ke- } t \\
& \alpha \quad=\text { konstanta pemulusan untuk data }(0 \leq \alpha \leq 1) \\
& \beta=\text { konstanta pemulusan untuk estimasi trend }(0 \leq \beta \leq 1) \\
& \gamma \quad=\text { konstanta pemulusan untuk estimasi musiman }(0 \leq \gamma \leq 1) \\
& L=\text { Panjang musiman } \\
& x_{t}=\text { Data ke- } t \\
& m=\text { Jumlah periode ramalan } \\
& F_{t}=\text { Nilai peramalan pada waktu ke- } t
\end{aligned}
$$

Metode peramalan yang paling sesuai pada umumnya ditentukan dengan melihat kesalahan peramalan yang terkecil. Menghitung kesalahan peramalan sering pula disebut dengan menghitung ketepatan pengukuran (accuracy measures). Untuk menguji ketepatan peramalan, maka dibutuhkan indikator ketepatan ramalan. Adapun indikator ketepatan peramalan yang digunakan dalam peramalan inflasi ini adalah sebagai berikut (Bowerman, O’Connell, Koehler, \& Bowerman, 2005):

\section{MSE (Mean Squared Error)}

$M S E=\frac{1}{n} \sum_{t=1}^{n}\left(Y_{t}-\hat{Y}_{t}\right)^{2}$.

MAPE (Mean Absolute Percentage Error)

$M A P E=\frac{1}{n} \sum_{t=1}^{n}\left|\frac{Y_{t}-\hat{Y}_{t}}{Y_{t}}\right| \times 100$. 
RMSE (Root Mean Square Error)

$R M S E=\sqrt{\frac{1}{n} \sum_{t=1}^{n}\left(Y_{t}-\hat{Y}_{t}\right)^{2}}$

dimana:

$$
\begin{aligned}
& Y_{t}=\text { nilai data time series pada periode } t \\
& \hat{Y}_{t}=\text { nilai ramalan dari } Y_{t} \\
& n=\text { jumlah periode waktu data }
\end{aligned}
$$

\section{HASIL DAN PEMBAHASAN}

Data yang digunakan dalam penelitian ini adalah data laju inflasi bulanan Provinsi Aceh dari bulan Januari 2011 sampai dengan bulan Desember 2018. Sebagai langkah awal penelitian, data disajikan dalam bentuk grafik pada Gambar 1 untuk melihat pola dari data yang digunakan.

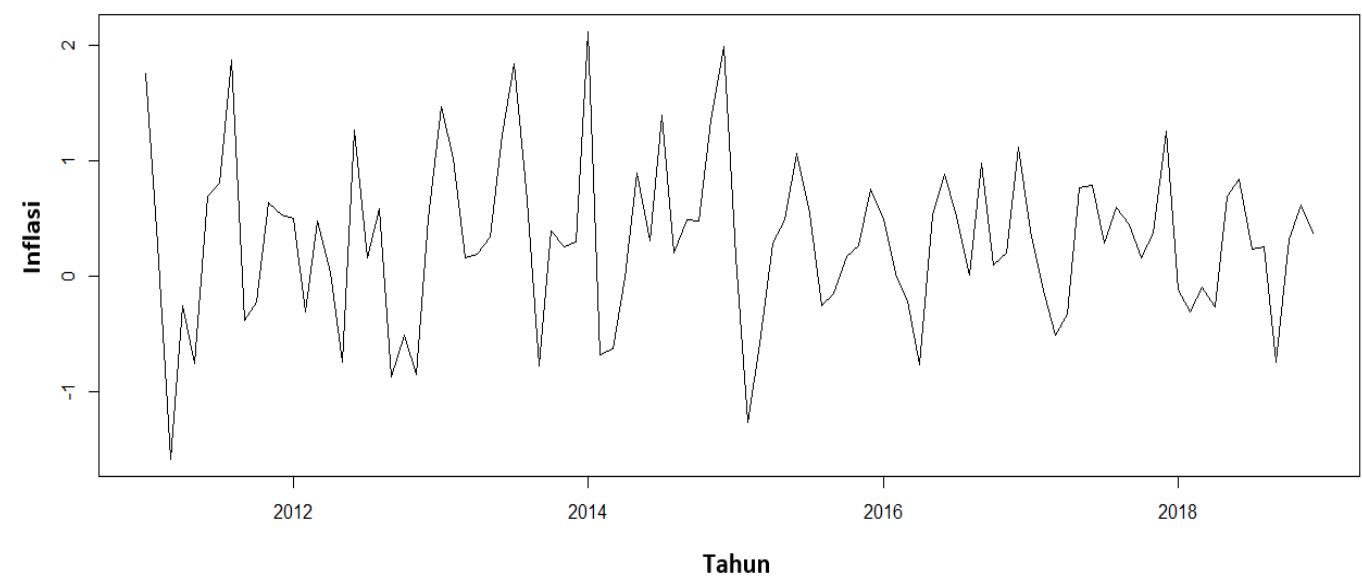

Gambar 1. Pola data laju inflasi Provinsi Aceh

Gambar 1 menunjukkan bahwa pola data laju inflasi bulanan Provinsi Aceh memiliki pola musiman atau mengalami kenaikan dan penurunan secara ekstrem dan cenderung berulang pada periode selanjutnya.

Langkah selanjutnya sebelum dilakukan proses peramalan adalah membagi data menjadi dua bagian yaitu data training dan testing. Data laju inflasi mulai dari 
bulan Januari 2011 sampai dengan bulan Desember 2017 digunakan sebagai data training, sedangkan data laju inflasi mulai dari bulan Januari 2018 sampai dengan bulan Desember 2018 digunakan sebagai data testing. Data training digunakan untuk membangun model tentatif dengan berbagai kombinasi parameter pemulusan $(\alpha, \beta, \gamma)$. Berbeda dengan data training, data testing digunakan untuk mengetahui tingkat akurasi dari hasil peramalan, sehingga dapat ditentukan model terbaik yang akan digunakan untuk meramalkan laju inflasi bulanan Provinsi Aceh periode 2019-2020.

Metode triple exponential smoothing menggunakan tiga konstanta pemulusan. Pertama, alpha $(\alpha)$ yang merupakan parameter yang mengontrol penghalusan relatif pada pengamatan yang baru dilakukan. Kedua, beta $(\beta)$ yang merupakan parameter yang mengontrol penghalusan relatif pada pengamatan yang baru dilakukan untuk mengestimasi kemunculan unsur kecenderungan atau trend. Ketiga, gamma $(\gamma)$ merupakan parameter yang mengontrol penghalusan relatif pada pengamatan yang baru dilakukan untuk mengestimasi kemunculan unsur musiman. Dalam penelitian ini, nilai alpha $(\alpha)$, beta $(\beta)$ dan gamma $(\gamma)$ ditentukan dengan cara trial and error untuk meminimumkan nilai error hasil peramalan terhadap data testing. Variasi nilai alpha $(\alpha)$, beta $(\beta)$ dan gamma $(\gamma)$ yang digunakan dalam penelitian ini ditunjukkan pada Tabel 1.

Tabel 1.

Variasi Parameter Pemulusan

\begin{tabular}{cccc}
\hline Model Tentatif & $\boldsymbol{\alpha}$ & $\boldsymbol{\beta}$ & $\boldsymbol{\gamma}$ \\
\hline Model 1 & 0,100 & 0,200 & 0,300 \\
Model 2 & 0,300 & 0,200 & 0,100 \\
Model 3 & 0,100 & 0,300 & 0,400 \\
Model 4 & 0,200 & 0,300 & 0,400 \\
\hline & & & Bersambung
\end{tabular}


Lanjutan

Tabel 1.

Variasi Parameter Pemulusan

\begin{tabular}{cccc}
\hline Model Tentatif & $\boldsymbol{\alpha}$ & $\boldsymbol{\beta}$ & $\boldsymbol{\gamma}$ \\
\hline Model 5 & 0,500 & 0,600 & 0,700 \\
Model 6 & 0,200 & 0,500 & 0,100 \\
Model 7 & 0,300 & 0,100 & 0,500 \\
Model 8 & 0,045 & 0,034 & 0,490 \\
\hline
\end{tabular}

Sumber: BPS Aceh, 2011 - 2018, Data diolah

Berdasarkan Tabel 1 dapat diketahui bahwa terdapat 8 model tentatif yang dibangun dengan nilai parameter pemulusan yang berbeda yang kemudian akan dipilih model tentatif dengan nilai error peramalan terkecil.

Setelah membangun model tentatif dengan data training, maka kedelapan model tentatif tersebut akan digunakan dalam meramalkan data testing untuk melihat ketepatan peramalannya. Metode peramalan yang paling baik ditentukan dengan melihat kesalahan peramalan yang terkecil melalui indikator ketepatan ramalan. Tiga indikator yang digunakan untuk menghitung tingkat ketepatan ramalan dalam penelitian ini adalah MSE (Mean Squared Error), MAPE (Mean Absolute Percentage Error), dan RMSE (Root Mean Square Error). Nilai MSE, MAPE, dan RMSE dari kedelapan model tentatif yang dibangun disajikan pada Tabel 2.

Tabel 2.

Tingkat kesalahan peramalan

\begin{tabular}{cccc}
\hline Model & MSE & MAPE & RMSE \\
\hline Model 1 & 0,311 & 1,526 & 0,558 \\
Model 2 & 0,801 & 3,024 & 0,895 \\
Model 3 & 0,268 & 1,438 & 0,518 \\
Model 4 & 0,344 & 1,572 & 0,586 \\
Model 5 & 0,416 & 1,949 & 0,645 \\
Model 6 & 1,094 & 3,336 & 1,046 \\
Model 7 & 0,331 & 1,548 & 0,575 \\
Model 8* $^{*}$ & 0,213 & 1,322 & 0,462 \\
\hline
\end{tabular}

Keterangan: * model dengan nilai error peramalan terkecil

Sumber: BPS Aceh, 2011 - 2018, Data diolah 
Tabel 2 menunjukkan perbandingan tingkat error peramalan dari kedelapan model tentatif yang dibangun. Model yang menghasilkan tingkat error peramalan terkecil diantara model tentatif lainnya adalah model 8 dengan nilai MSE sebesar 0,2132, nilai MAPE sebesar 1,3224 , dan nilai RMSE sebesar 0,4618 . Model 8 tersebut memiliki nilai parameter alpha $(\alpha)=0,045$; beta $(\beta)=0,034$ dan gamma $(\gamma)=0,490$. Model 8 tersebut merupakan model terbaik berdasarkan kriteria nilai MSE, MAPE dan RMSE serta akan digunakan untuk meramalkan laju inflasi bulanan Provinsi Aceh periode 2019-2020.

Peramalan data laju inflasi bulanan Provinsi Aceh periode 2019-2020 dilakukan dengan menggunakan model 8 yang memiliki nilai alpha $(\alpha)=0,045$; beta $(ß)=0,034$ dan gamma $(\gamma)=0,490$. Hasil peramalan laju inflasi bulanan tersebut ditampilkan pada Tabel 3.

Tabel 3.

Data peramalan laju inflasi bulanan Provinsi Aceh periode 2019-2020

\begin{tabular}{lclc}
\hline Bulan-Tahun & $\begin{array}{c}\text { Data } \\
\text { Peramalan }\end{array}$ & Bulan-Tahun & $\begin{array}{c}\text { Data } \\
\text { Peramalan }\end{array}$ \\
\hline Januari-2019 & 0,10 & Januari-2020 & 0,04 \\
Februari-2019 & $-0,37$ & Februari-2020 & $-0,43$ \\
Maret-2019 & $-0,36$ & Maret-2020 & $-0,42$ \\
April-2019 & $-0,41$ & April-2020 & $-0,47$ \\
Mei-2019 & 0,53 & Mei-2020 & 0,47 \\
Juni-2019 & 0,71 & Juni-2020 & 0,65 \\
Juli-2019 & 0,24 & Juli-2020 & 0,18 \\
Agustus-2019 & 0,18 & Agustus-2020 & 0,12 \\
September-2019 & $-0,27$ & September-2020 & $-0,33$ \\
Oktober-2019 & 0,12 & Oktober-2020 & 0,06 \\
November-2019 & 0,37 & November-2020 & 0,31 \\
Desember-2019 & 0,64 & Desember-2020 & 0,58 \\
\hline Sumber: BPS Aceh, $2011-2018$, Data diolah & &
\end{tabular}

Hasil peramalan laju inflasi bulanan tersebut juga dapat disajikan dalam bentuk grafik pada Gambar 2. 


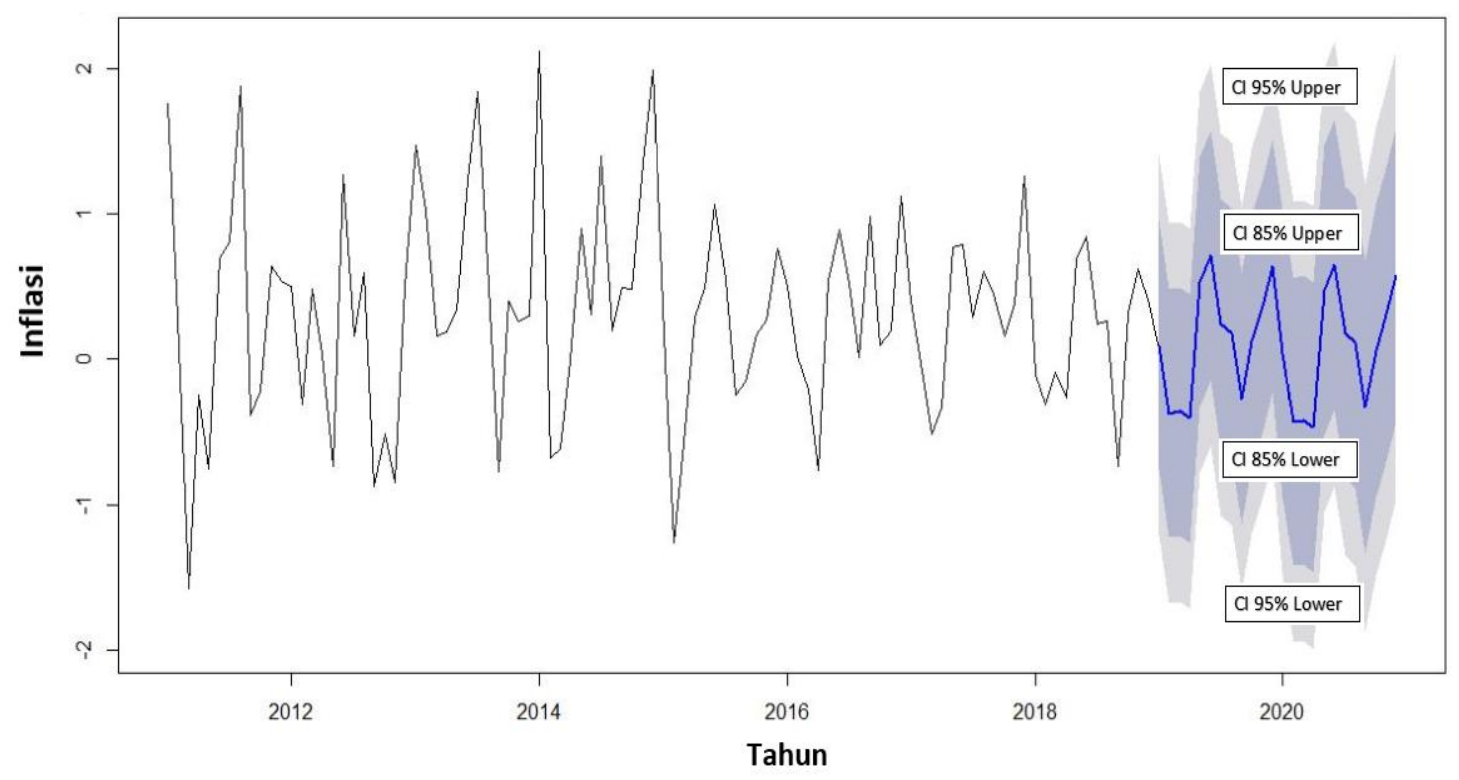

Gambar 2.

Plot hasil peramalan laju inflasi Provinsi Aceh periode 2019-2020

Gambar 2 menunjukkan bahwa plot hasil peramalan (garis biru) laju inflasi bulanan Provinsi Aceh periode 2019-2020 cenderung mengikuti pola data sebelumnya (garis hitam). Selain menunjukkan nilai peramalan laju inflasi, Gambar 2 juga menunjukkan selang kepercayaan peramalan $85 \%$ dan $95 \%$. Daerah yang berwarna biru menunjukkan nilai interval peramalan dengan selang kepercayaan $85 \%$, sedangkan daerah yang berwarna abu-abu menunjukkan nilai interval peramalan dengan selang kepercayaan 95\%. Hasil peramalan laju inflasi bulanan tertinggi diperkirakan akan terjadi pada bulan Juni 2019 sebesar 0,71. Sedangkan laju inflasi bulanan terendah diperkirakan akan terjadi pada bulan April 2020 yaitu sebesar $-0,47$.

Berdasarkan Tabel 3 dan Gambar 2, dapat disimpulkan bahwa laju inflasi bulanan di Provinsi Aceh cenderung tinggi pada bulan Juni dan Desember dan rendah pada bulan Februari hingga April. Laju inflasi bulanan Provinsi Aceh pada 
tahun 2019 diperkirakan akan berada pada kisaran -0,41 - 0,71. Sedangkan untuk tahun 2020, laju inflasi bulanan Provinsi Aceh diperkirakan akan berada pada interval antara -0,47 hingga 0,65. Menurut Bhima Yudhistira Adhinegara, peneliti Institute for Development of Economics and Finance (INDEF), terjadinya inflasi yang cenderung tinggi pada akhir tahun disebabkan karena adanya kenaikan permintaan terhadap produk pangan dan transportasi, ditambah dengan realisasi pemerintah akhir tahun (Detik Finance, 2019). Sementara itu, Gubernur Bank Indonesia Perry Warjiyo menyebutkan bahwa rendahnya inflasi pada awal tahun dikarenakan harga barang-barang yang cenderung terjaga. Stabilitas harga tersebut menyebabkan terkendalinya inflasi inti, inflasi komponen harga pangan bergejolak (volatile food) maupun inflasi komponen harga pangan yang telah diatur pemerintah (administered prices) (Kompas, 2019). Menurut Ferayanti et al. (2014), pemerintah melalui kebijakan moneter dapat menstabilkan nilai tukar rupiah (kurs) dan melalui kebijakan fiskal dapat mengatasi kesenjangan pendistribusian pendapatan kepada masyarakat serta dapat menghindari pengeluaran pemerintah yang terlalu berlebihan sehingga inflasi dapat dihindari. Inflasi bersama dengan PDRB perkapita dan tingkat pengangguran berpengaruh nyata terhadap jumlah penduduk miskin di Provinsi Aceh (Nasir, 2004). Muttaqim, Hamdani dan Husin (2019) menunjukkan bahwa inflasi memiliki pengaruh yang signifikan terhadap tingkat konsumsi masyarakat Aceh terutama dalam jangka panjang. Inflasi yang tinggi cenderung menekan tingkat konsumsi masyarakat karena ketidakmampuan dalam membeli bahan kebutuhan pokok yang mengalami kenaikan harga akibat inflasi. 


\section{SIMPULAN DAN SARAN}

Peramalan laju inflasi yang mungkin akan terjadi pada masa yang akan datang merupakan hal yang penting untuk dilakukan. Pemerintah Aceh dapat mempersiapkan langkah-langkah strategis dalam upaya menghindari terjadinya inflasi yang tinggi pada masa yang akan datang berdasarkan informasi dari peramalan inflasi tersebut. Berdasarkan metode triple exponential smoothing terbaik, laju inflasi bulanan Provinsi Aceh diperkirakan akan memiliki pola musiman atau mengalami kenaikan dan penurunan yang cenderung berulang pada periode selanjutnya. Laju inflasi bulanan di Provinsi Aceh diperkirakan cenderung tinggi pada bulan Juni dan Desember dan rendah pada bulan Februari hingga April. Laju inflasi Provinsi Aceh tahun 2019 diperkirakan akan berada pada interval -0,41 hingga 0,71. Sedangkan untuk tahun 2020, laju inflasi Provinsi Aceh diperkirakan akan berada pada interval antara $-0,47$ hingga 0,65 .

Saran yang dapat diberikan bagi peneliti selanjutnya adalah memperbanyak periode data penelitian sehingga pola data menjadi lebih terlihat. Selain itu, peneliti lainnya juga disarankan untuk mencoba beberapa metode peramalan lainnya seperti Autoregressive Integrated Moving Average with Exogenous Variables (ARIMAX) maupun Seasonal Autoregressive Integrated Moving Average (SARIMA). Assakhiy, Anwar \& Fitriana (2019) menunjukkan bahwa metode ARIMAX lebih baik dari pada metode SARIMA dalam meramalkan realisasi penerimaan zakat pada Baitul Mal Aceh. Bagi Pemerintah Aceh, penelitian ini dapat menjadi acuan dalam penentuan kebijakan terutama yang berkaitan dengan pengendalian laju inflasi di Provinsi Aceh. Pemerintah Aceh disarankan untuk menyiapkan langkah- 
langkah khusus dalam upaya pengendalian laju inflasi yang tinggi. Kebijakan yang dapat diambil oleh Pemerintah Aceh untuk menjaga agar inflasi tetap stabil adalah dengan menjaga kelancaran pasokan produk-produk yang menyebabkan laju inflasi meningkat terutama pada akhir tahun.

\section{REFERENSI}

Anwar, S. (2017). Peramalan Suhu Udara Jangka Pendek di Kota Banda Aceh dengan Metode Autoregressive Integrated Moving Average (ARIMA). Malikussaleh Journal of Mechanical Science and Technology, 5(1), 6-12.

Assakhiy, R., Anwar, S., \& Fitriana, AR. (2019). Peramalan Realisasi Penerimaan Zakat pada Baitulmal Aceh dengan Mempertimbangkan Efek dari Variasi Kalender. Jurnal Ekonomi dan Pembangunan, 27(2), 27-45. https://doi.org/10.14203/JEP.27.2.2019.27-45

Bowerman, B. L., O’Connell, R. T., Koehler, A. B., \& Bowerman, B. L. (2005). Forecasting, time series, and regression : an applied approach.

Massachusetts: Thomson Brooks/Cole.

BPS Provinsi Aceh. (2011). Aceh Dalam Angka 2011. Banda Aceh: Badan Pusat Statistik Provinsi Aceh.

BPS Provinsi Aceh. (2012). Aceh Dalam Angka 2012. Banda Aceh: Badan Pusat Statistik Provinsi Aceh.

BPS Provinsi Aceh. (2013). Aceh Dalam Angka 2013. Banda Aceh: Badan Pusat Statistik Provinsi Aceh.

BPS Provinsi Aceh. (2014). Aceh Dalam Angka 2014. Banda Aceh: Badan Pusat Statistik Provinsi Aceh.

BPS Provinsi Aceh. (2015). Provinsi Aceh Dalam Angka 2015. Banda Aceh: Badan Pusat Statistik Provinsi Aceh.

BPS Provinsi Aceh. (2016). Provinsi Aceh Dalam Angka 2016. Banda Aceh: Badan Pusat Statistik Provinsi Aceh.

BPS Provinsi Aceh. (2017). Provinsi Aceh Dalam Angka 2017. Banda Aceh: Badan Pusat Statistik Provinsi Aceh.

BPS Provinsi Aceh. (2018a). Perkembangan Indikator Sosial Ekonomi Provinsi Aceh 2018. Banda Aceh: Badan Pusat Statistik Provinsi Aceh.

BPS Provinsi Aceh. (2018b). Provinsi Aceh Dalam Angka 2018. Banda Aceh: Badan Pusat Statistik Provinsi Aceh.

Detik Finance. (2019, January 2). Inflasi Desember Diprediksi Lebih Tinggi dari November 2018. Detikfinance. Retrieved from https://finance.detik.com/berita-ekonomi-bisnis/d-4367609/inflasi-desemberdiprediksi-lebih-tinggi-dari-november-2018

Ferayanti, F., Masbar, R., \& Syahnur, S. (2014). Analisis Faktor - Faktor yang Mempengaruhi Inflasi di Provinsi Aceh. Jurnal Ilmu Ekonomi : Program 
Pascasarjana Unsyiah, 2(2), 14-21.

Fitri, A., Anwar, S., Zohra, A. F., \& Nasution, M. H. (2018). Peramalan Laju Inflasi Bulanan Kota Padang Menggunakan Metode Triple Exponential Smoothing. Jurnal Ilmiah Sosio-Ekonomika Bisnis, 21(2), 1 - 10. https://doi.org/10.22437/jiseb.v21i2.6050

Holt, C. C. (2004). Forecasting seasonals and trends by exponentially weighted moving averages. International Journal of Forecasting, 20(1), 5-10. https://doi.org/10.1016/J.IJFORECAST.2003.09.015

Kompas. (2019, January 4). BI Prediksi Inflasi Awal Tahun Rendah. Retrieved from https://ekonomi.kompas.com/read/2019/01/04/152400026/bi-prediksiinflasi-awal-tahun-rendah

Makridakis, S., Wheelwright, S. C., \& Hyndman, R. J. (1998). Forecasting: Methods and Applications. New Jersey: John Wiley \& Sons, Inc.

Muttaqim, H., Hamdani, H., \& Husin, D. (2019). Inflasi, Tingkat Suku Bunga, dan Konsumsi di Provinsi Aceh. Ekspansi: Jurnal Ekonomi, Keuangan, Perbankan dan Akuntansi, 11(2), 285-295. https://doi.org/10.35313/ekspansi.v11i2.1627

Nasir, N. (2014). Pengaruh PDRB, Inflasi dan Pengangguran terhadap Jumlah Penduduk Miskin di Provinsi Aceh. Jurnal Serambi Ekonomi dan Bisnis, 1(1), 59-64.

Nasution, M. H., Anwar, S., Fitri, A., \& Zohra, A. F. (2019). Forecasting The Amount of Tuna/Madidihang (Yellowfin tuna) Landed in PPS Kutaraja Banda Aceh City With The Triple Exponential Smoothing Method. Samakia : Jurnal Ilmu Perikanan, 10(1), 08-14. https://doi.org/10.35316/jsapi.v10i1.231

Pranata, A., Akbar Hsb, M., Akhdansyah, T., \& Anwar, S. (2018). Penerapan Metode Pemulusan Eksponensial Ganda dan Tripel Untuk Meramalkan Kunjungan Wisatawan Mancanegara ke Indonesia. Journal of Data Analysis, 1(1), 32-41. https://doi.org/10.24815/jda.v1i1.11873

Santoso, S. (2009). Business Forecasting : Metode Peramalan Bisnis Masa Kini dengan Minitab dan SPSS. Jakarta: Elex Media Komputindo.

Yusri, F. (2016). Analisis Pengaruh Jumlah Uang Beredar Terhadap Inflasi di Provinsi Aceh. Skripsi. Universitas Teuku Umar. 